\title{
Seasonal Variation of PAHs in Marshy Soils from Warri City, Nigeria
}

\section{Adejoke Victoria Bayowa1 ${ }^{1}$, Iwekumo Ebibofe Agbozu²}

\author{
${ }^{1}$ Department of Environmental Sciences, University of South Africa, Pretoria, South Africa \\ ${ }^{2}$ Department of Environmental Sciences, Federal University of Petroleum Resources, Effurun Delta State, Nigeria
}

\begin{abstract}
Seasonal variation has been used to analyse the levels of Polycyclic Aromatic Hydrocarbons PAHs in marshy soils in Warri city, Niger Delta region in Southern Nigeria. Soil samples were collected from four locations in Warri city- Ekpan, Ogunu, Ugboroke, and Okotie sawmill and labelled ST 1, ST 2, ST 3 and ST 4 respectively. Control samples were also collected at Agbarho, 20km away from Warri and labelled ST 5. The objective of this study is to compare marshy soil levels of PAHs in dry and rainy season and examine their variation base on the type of PAHs detected in relation to the characteristics of the different locations. The samples were collected from January to March for dry season and June to August for rainy/wet season. Levels of 16 USEPA priority PAHs were determined using GC-FID. Highest total concentration for individual PAHs in the soil samples was $1.069 \mathrm{mg} / \mathrm{kg}$ for benzo(a)pyrene in dry season ST4 (Okotie sawmill) sample. At the control station ST 5, sample with highest dry season concentration was $0.519 \mathrm{mg} / \mathrm{kg}$ of benzo(ghi)perylene. In the rainy season, PAHs were majorly below detection limit or found in minute quantity at the study location and control. ST4 had highest total PAHs concentration of $1.911 \mathrm{mg} / \mathrm{kg}$ in dry season. The station with the lowest concentration was ST1 with a value of $0.009 \mathrm{mg} / \mathrm{kg}$ in rainy season. The results of this analysis further revealed that total PAHs concentration in Warri city were higher than at the control station (Agbarho).
\end{abstract}

Keywords: Benzo(a) Pyrene; Concentration; Dry Season; Niger Delta; Rainy Season

\section{Introduction}

Polycyclic Aromatic Hydrocarbons (PAHs) are a family of organic compounds of the six carbon benzene ring origin; the benzene ring is the one responsible for their aromatic behaviour and they are made up of a few to several fused rings of benzene hydrocarbon compounds (Kouakou et al., 2015) There are several hundreds of different known PAHs and related compounds and the number of rings could be from two for the lower molecular weight compounds to seven for the higher molecular weight PAHs (World Health Organisation WHO, 2003). Some of the known PAHs are: Naphthalene(Naph.), Anthracene(Ant.),

Acenaphtylene(Acp),

Acenaphthene(Acn),

Fluorene(Fluo),

Chrysene(Chr), Pyrene(Pyr),

Benzo(a)Pyrene(B(a)P, Fluoranthene(Fluoran), Benzo(e)Pyrene(B(e)P, Benzo(a)anthracene(B(a)A, Benzo(b)fluoranthene(B(b)F, Phenanthrene(Phe), Benzo(a)pyrene(B(a)P, Benzo(k)fluoranthene $(\mathrm{B}(\mathrm{k}) \mathrm{F}$, Indeno(1,2,3-cd)Pyrene(Ind)

and Dibenzo(a,h)Anthracene(Db(ah)A (Buha \& Lah, 2011). The structure of the 16 PAHs that are termed as priority pollutants by the World Health Organisation is shown in Figure 1.
This study is set out to compare how rainy and dry season could impact on PAHs distribution and variation in soil samples collected at the study location (Warri City) and control (Agbarho).

Polycyclic aromatic hydrocarbons (PAHs) in an environment have often been used as one of the many compounds that could reflect the history of fossil fuel combustion (Ekonomiuk et al., 2006). PAHs in soil are usually from atmospheric deposition due to pyrolytic sources such as vehicular exhaust and smoke from cooking or burning (Teaf, 2008). Other sources which are termed as petrogenic includes: release of petroleum or crude oil from natural oil seeps, spillage and other activities that involve these (Teaf, 2008). In the soil, they are usually found attached to substrates or any oily contaminants present there (Delgado, 2000). They have high sorption capacity (attached strongly to substrate) and are less volatile; as a result, they persist for a long time in the soil (Obayori \& Salaam, 2010). It has been found that the soil as well as sediment are good environmental sink for PAHs and could contain about $90 \%$ of these compounds with longer half-life than the atmosphere or in plants (Ekonomiuk et al., 2006).

This article is published under the terms of the Creative Commons Attribution License 4.0

Author(s) retain the copyright of this article. Publication rights with Alkhaer Publications.

Published at: http://www.ijsciences.com/pub/issue/2018-02/

DOI: 10.18483/ijSci.1469; Online ISSN: 2305-3925; Print ISSN: 2410-4477 
Some PAHs are also sparingly soluble in soil-water and therefore may be found as dissolved there and could enter groundwater and be transported within an aquifer (EFSA, 2008), although this is possible only among the lower molecular weight compounds with two to three rings (Karlsson \& Viklander, 2008).

PAHs in urban soil may be thought of and have actually been found to be more than that of rural area, due to the increase in vehicular and industrial activities in the urban areas. Such PAHs are majorly of the anthropogenic pyrolytic sources (Environmental Forensics Contaminant Specific Guide EFCS, 2010). However, most crude oil or petroleum exploits and their related production and activities are usually cited in the rural areas with their administrative centres at the nearest urban area (most of the time, it is the presence of the petroleum companies and their related activities that urbanise the areas); accidental or intentional spillage of oil fractions from the exploitation and production activities could therefore also increase PAHs in soil from petrogenic sources in addition to those from pyrolytic sources in the rural areas.

The study area - Warri has in the last few years experienced an increase in industrial and commercial activities due to the large crude oil deposit found in the Niger Delta and subsequent influx of oil exploration and production activities with the associated gains and pains (Egborge \& Olomukoro, 2004). PAHs being ubiquitous pollutants are found almost everywhere in the environment with their final destination (if not inhaled) usually in soil and aquatic environment (Kouakou et al., 2015). Due to the large crude oil reserves in this study area, and exploration and production activities going on, there are usually issues of oil spillage, pipeline vandalism, sabotage, oil refining activities and other industrial petroleum related practices in this part of the country which could possibly lead to the introduction of PAHs as well as other petroleum hydrocarbons and pollutants into the soil and waterways that the people largely feed from. The people of Warri and generally those in the western part of Nigeria Niger Delta are known to be fishermen/women; probably due to their proximity to the rivers and seas, they eat lots of fishes and sea foods as well as selling them to other parts of the country and beyond (Egborge \& Olomukoro, 2004). Also, some farm crops such as maize, vegetables and cassava are cultivated in a few communities in the city.

Polycyclic Aromatic Hydrocarbons are important environmental pollutants that have been studied in many places. Their harmful tendencies in the environment especially in humans have also been issues of discussion in many reviews and they have been included in WHO priority list as harmful environmental pollutants. All these poised the motivation for embarking on this study titled Seasonal Variation of Polycyclic Aromatic Hydrocarbons PAHs in Marshy Soils in Warri City. The study analysed levels of PAHs in the two atmospheric weather seasons in Nigeria, the study country which are: Dry and Rainy/Wet season.

\section{Atmospheric Weather Seasons in Nigeria}

Dry season and Rainy/Wet season are the two major atmospheric weather seasons in Nigeria. The dry season runs from November to April while the wet season is from May to October. During dry season, the weather is usually warmer than the rainy season. This season usually records a notably high temperature, low humidity and little or no rainfall. There is also harmattan in this period which is characterised by early morning dry windy but cold weather and characteristic hot sunny afternoons (Egborge \& Olomukoro, 2004). The amount of rainfall starts decreasing from October towards November during the dry season.

The rainy/wet season is the period of the year when it rains regularly and almost every day. The weather is cooler than the dry season and there is more rainfall than sunshine. In this season, there is also a period of high rainfall and that of low rainfall and humidity is usually high (Egborge \& Olomukoro, 2004). The amount of rainfall starts increasing from end of March to beginning of April and peaks in June and July. However, there has been variation in the amount of rainfall and sunshine in any particular geographical area due to global climatic change and environmental changes peculiar to a given location (Botkin \& Keller, 2005). Consequently, different part of the country experience varying amount of the atmospheric weather condition every year. And the Niger delta part of Nigeria where Warri city is located is usually characterised by a longer period of rainy season and a short period of dry season (Egborge \& Olomukoro, 2004).

\subsection{Description of Study/Sampling Location}

Warri also known as 'Oil City' is a small commercial city in Delta state southern Nigeria in the oil rich Niger delta region. It is located at an elevation of about 1 meter above sea level and the coordinate is as indicated: $5^{\circ} 31^{\prime} \mathrm{N} 5^{\circ} 45^{\prime} \mathrm{E} 5.517^{\circ} \mathrm{N} 5.75^{\circ} \mathrm{E}$. The map of Nigeria in Figure 2 shows Warri in lower Niger delta region.

Warri is one of the wettest regions in the Niger delta with rainfall of about eight to ten months majorly from May to October and only about three to four months of dry season - November to March (Egborge \& Olomukoro, 2004). The dry season is significantly marked by the cool "harmattan" dusty 
haze from the north-east winds. However, it frequently rains even in the dry season. The area is characterized by tropical equatorial climate with mean annual temperature of $32.8{ }^{\circ} \mathrm{C}$ and annual rainfall amount of $2673.8 \mathrm{~mm}$ and there are high temperatures of $36{ }^{\circ} \mathrm{C}$ and $37{ }^{\circ} \mathrm{C}$ (Egborge \& Olomukoro, 2004).

The land area in Warri and its environs are majorly marshy and mostly sand filled or composted before building structures are erected. Warri River which is one of the most important coastal rivers of the Niger delta distributed in various tributaries around the city and beyond, together with high level of rainfall is responsible for the marshy soil and swampy area that characterise the city (Egborge \& Olomukoro, 2004).

\section{MATERIALS AND METHODS \\ 2.1 Sampling Sites}

Five areas were strategically chosen, four within Warri and one outside Warri- Agbarho; the one outside Warri was chosen to serve as a check or control to the other sites.

1. Ekpan-NNPC Complex area Co-ordinates: $05^{\circ} 33^{\prime} 13.5 \mathrm{sN} 005^{\circ} 44^{\prime} 35.8 \mathrm{sE}$

2. Ogunu (SPDC Industrial Area) $05^{\circ} 31^{\prime}$ $48.1 \mathrm{sN} 005^{\circ} 42^{\prime} 44.9 \mathrm{sE}$

3. Ugboroke community (Kingdom Development Centre) $05^{\circ} 32^{\prime} 37.6 \mathrm{sN} 005^{\circ}$ $44^{\prime} 50.5 \mathrm{sE}$

4. Okotie Sawmill, Effunrun $05^{\circ} 32^{\prime} 23.3 \mathrm{sN}$ $005^{\circ} 47^{\prime} 24.0 \mathrm{sE}$

5. Agbarho river (control) $05^{\circ} 35^{\prime} 01.1 \mathrm{sN} 005^{\circ}$ $50^{\prime} 56.0 \mathrm{sE}$

The sample location map is shown in Figure 3.

\subsection{Sampling}

Soil samples from the five sampling points were collected every month for six months; three months in the dry season (January - March) and three months in the rainy season (June - August). The samples were collected using stainless steel grab sampler into an aluminium foil; Top $(0-15 \mathrm{~cm})$ and bottom $(15-$ $30 \mathrm{~cm}$ ) samples were collected at each point to form one composite sample and a total of ten samples of soil were collected for each month in the dry season (January-March) and in the wet season (JuneAugust).

The samples were wrapped in aluminium foil and properly preserved by cooling in a refrigerator at $\left(4^{\circ} \mathrm{c}\right)$ pending further treatment in the laboratory.

\subsection{Sample Treatment/Analysis}

The standard reference method employed in the PAH analysis is USEPA $8240.10 \mathrm{~g}$ of sample was carefully weighed into a dried organic free and chromic acid pre-cleaned extraction bottle and $10 \mathrm{~g}$ of anhydrous Sodium Sulphate was added and mixed with a glass rod. Thereafter, $20 \mathrm{ml}$ of Hexane:Dichloromethane in the ratio $3: 1 \quad(90 \mathrm{ml}$ of Hexane and $30 \mathrm{ml}$ of Dichloromethane were mixed and prepared in a standard flask) was added to the sample. The sample was then placed in an organic flask shaker at $500 \mathrm{osc} / \mathrm{min}$ for $30 \mathrm{mins}$ and the extract was filtered. The sample was then left in the extraction bottle at laboratory room temperature to concentrate for a minimum of 24 hours until about $2 \mathrm{ml}$ of concentrated sample was left in the extraction bottle. This was followed by fractionation in activated alumina (neutral) column to separate into aliphatic and aromatic fractions using n-Hexane and Dichloromethane respectively; the aromatic fraction was concentrated to approximately $1.0 \mathrm{ml}$ using rotary evaporator and the extract, stored in a dried organic free and chromic acid pre-cleaned glass vials with Teflon rubber caps for analysis. It was then refrigerated at $-4^{\circ} \mathrm{c}$ until analysis.

Analysis was done using Gas Chromatography GC. $1 \mu \mathrm{l}$ of the concentrated sample was injected by means of exmire micro syringe through rubber septum into the column. Separation occurs as the vapour constituent partition between the gas and liquid phases. The sample was automatically detected as it emerges from the column by a Flame Ionisation Detector FID. PAH quantification was carried out by CLARITY-GC interfaced software.

\section{RESULTS}

The results of analysis of the soil samples from the study area and control for dry (D) and rainy/wet (R) seasons of sampling are as presented in Table 1. The four sampling stations within Warri City are represented as ST 1- ST 4 (ST 1-Ekpan NNPC complex area, ST 2 - Ogunu SPDC Industrial area, ST 3 Ugboroke Kingdom Development area and ST 4 Okotie Sawmill). The control station Agbarho is represented as ST 5. The results were read as the detection limit on the gas chromatogram for individual PAHs which were in microgram per litre and these were converted to milligram per kilogram or $\mathrm{mg} / \mathrm{kg}$. The minimum detection limit for GCFID used in the analysis on the chromatogram is $1 \times 10^{-3}$ $\mathrm{mg} / \mathrm{kg}$. The PAHs analysed in this study are: Naphthalene(Naph.), 2-methyl naphthalene, 1-methyl naphthalene,

Acenaphthene(Acn), Acenaphtylene(Acp), Fluorene(Fluo), Phenanthrene(Phe), Antracene(Ant), Pyrene(Pyr), Chrysene(Chry), Fluoranthene(Fluoran),

Benzo(a)anthracene(B(a)A),

Benzo(b)fluoranthene $(\mathrm{B}(\mathrm{b}) \mathrm{F})$,

Benzo(k)fluoranthene $(\mathrm{B}(\mathrm{k}) \mathrm{F})$,

Benzo(a)Pyrene(B(a)P),

Dibenzo(a,h)anthracene(Db(ah)A and Indeno(1,2,3cd)Pyrene (Ind). The values for mean concentration of PAHs in soil samples are presented in table 1. 
Generally, it was observed that total PAH concentration was higher in the dry season samples at all sampling location including the control than rainy season. At the sampling station, benzo(a)pyrene had the highest concentration for individual PAH of $1.069 \mathrm{mg} / \mathrm{kg}$ at ST4 in dry season. This is followed by benzo(a)anthracene with a concentration of 0.567 $\mathrm{mg} / \mathrm{kg}$ in dry season ST3 samples. Dibenzo(a,h)anthracene and indeno(1,2,3-cd)pyrene also had a concentration of $0.555 \mathrm{mg} / \mathrm{kg}$ in ST2 dry season samples. In the rainy season, PAHs were majorly below detection limit at ST1 and ST3; ST2 and ST4 samples contained the pollutants in minute quantity. This was responsible for the overall low concentration values for the rainy season. However, benzo(b)fluoranthene and benzo(k)fluoranthene had the highest rainy season concentration of 0.091 $\mathrm{mg} / \mathrm{kg}$ followed by benzo(ghi)perylene of 0.074 $\mathrm{mg} / \mathrm{kg}$, both at ST2.

For the overall PAHs concentration at the different stations in dry season, ST4 (Okotie sawmill) had highest concentration of $1.911 \mathrm{mg} / \mathrm{kg}$ followed by ST2 with $1.608 \mathrm{mg} / \mathrm{kg}$. ST1 had lowest concentration of $1.113 \mathrm{mg} / \mathrm{kg}$. In the rainy season, ST2 had highest concentration of $0.443 \mathrm{mg} / \mathrm{kg}$ followed by ST 4 with $0.182 \mathrm{mg} / \mathrm{kg}$. The station with the lowest concentration of $0.009 \mathrm{mg} / \mathrm{kg}$ was ST1. At the control station, PAH with highest dry season concentration was $0.519 \quad \mathrm{mg} / \mathrm{kg}$ of benzo(ghi)perylene followed by benzo(b)fluoranthene and benzo(k)fluoranthene with a concentration of $0.257 \mathrm{mg} / \mathrm{kg}$. Benzo(a)pyrene was below detection limit at this station in dry season. In rainy season, 2methyl naphthalene had highest concentration of $0.137 \mathrm{mg} / \mathrm{kg}$, benzo(ghi)perylene was $0.0423 \mathrm{mg} / \mathrm{kg}$, benzo(b)fluoranthene and benzo(k)fluoranthene was $0.0176 \mathrm{mg} / \mathrm{kg}$ and benzo(a)pyrene was $0.022 \mathrm{mg} / \mathrm{kg}$. The value for total PAHs concentration in dry season was $0.982 \mathrm{mg} / \mathrm{kg}$ while the rainy season was $0.246 \mathrm{mg} / \mathrm{kg}$.

\section{Critical Analysis based on number of PAH Rings}

Two to three ringed PAHs

Naphthalene, 2-methyl naphthalene and 1-methyl naphthalene were the two ringed PAHs analysed in this study. They were majorly detected in the dry season at the study location and control. This agrees with previous studies which states that fewer ring PAHs disintegrates with ease and are soluble in aqueous solution (especially in rainy season) which makes them converted into other forms and not detectable as naphthalene (Botkin \& Keller, 2005). In previous work done by Bayowa and Agbozu while working in a similar environment in Warri, Nigeria, they analysed the methylated form of naphthalene in sediment and detected considerable amount, even in rainy season (Bayowa \& Agbozu, 2016). This methylated form has been found to be more stable in aqueous solution and harmful than the parent compound (Botkin \& Keller, 2005). For three ringed PAHs, anthracene and phenanthrene were detected more than the other three rings (which are: Fluorene, acenaphthelene and acanapthylene) in study locationWarri samples. And they were present more in the dry season than rainy season. One notable behaviour of these two three ringed $\mathrm{PAH}$-anthracene and phenanthrene is that, wherever one is found in minute quantity, the other too is present in minute quantity and wherever one is below detection limit, the other is also or almost below detection limit. At the control point, three-ringed fluorene had highest value and it was $0.0355 \mathrm{mg} / \mathrm{kg}$ in dry season. This PAH -fluorene was however below detection limit at most point at the sampling location. All the three-ringed PAHs analysed were not detectable at this point in rainy season.

\section{Four-ringed PAHs}

The four ringed PAH analysed in this study are: pyrene, chrysene, fluoranthene, and benzo(a)anthracene. Earlier studies have shown that PAHs with four rings and above are less acutely toxic but more carcinogenic and teratogenic (Padmini et $a l ., 2009)$. This is part of why their analysis is important to this study. Pyrene was the most persistence four-ring in Warri and their highest concentration was present in dry season in this sampling period. Although benzo(a)anthracene had highest concentration of $0.567 \mathrm{mg} / \mathrm{kg}$ in dry season ST3 samples, and was the second PAH with highest concentration at sampling location (Warri), yet, pyrene was detected at almost all the sampling points; which makes it more predominant. The order of persistence of four-ringed PAHs within Warri is Pyrene $>$ benzo(a)anthracene $>$ chrysene $>$ fluoranthene. At the control station, pyrene was also the only four ringed detected and this was in the dry season. In the rainy season, pyrene and fluoranthene were detected in minute quantity.

\section{Five to Six-ringed PAHs}

The five to six rings analysed in this study are: benzo(b)fluoranthene and benzo(k)fluoranthene, benzo(a)pyrene, dibenzo(a,h)anthracene and indeno(1,2,3 cd)pyrene and benzo(g,h,i)perylene. Five-ringed benzo(a)pyrene $(\mathrm{BaP})$ had highest value for individual $\mathrm{PAH}$ concentration at a given point of $1.069 \mathrm{mg} / \mathrm{kg}$ which was detected in dry season ST4 sample. Benzo(a)pyrene is believe to be of petrogenic origin (Neff, 2005). This PAH which is considered to be probably carcinogenic in human (EFSA, 2008), may likely be available in human consumables. Although $\mathrm{BaP}$ was below detection limits in the samples collected at ST4 in rainy season, yet, it has 
the highest value for the five to six ringed $\mathrm{PAH}$ analysed in this study period. However, Benzo(ghi)Perylene - BghiP was the most persistent six-ringed recorded in the study area - Warri, it was detected at all the sampling points. BghiP lowest value of $0.023 \mathrm{mg} / \mathrm{kg}$ was detected in ST3 samples in rainy season. At the control point, BghiP was also the most persistent and had its highest mean concentration of $0.519 \mathrm{mg} / \mathrm{kg}$ in soil in dry season. A mean value of $0.0423 \mathrm{mg} / \mathrm{kg}$ was the value for BghiP in rainy season control station samples.

\section{Seasonal Variation of PAHs in Soil}

From the results of this analysis, it was revealed that PAHs concentration in dry season was higher than rainy season. Most of the PAHs detected in this study were in the dry season and the rainy season samples were majorly below detection limit. Highest concentration for individual PAHs at study location and control was also in the dry season. This is similar to the results by Bayowa and Agbozu when they conducted similar analysis on sediment samples at same study location and control within similar period. They also found that PAHs concentration in the sediment samples in dry season were higher than the rainy season (Bayowa \& Agbozu, 2016).

Furthermore, seasonal variation of PAHs in this study revealed that locations with higher PAHs in dry season, were also high in rainy season and locations with lower concentrations in dry season were also low in rainy season. ST4 was higher in dry season followed by ST2, while ST2 was higher in rainy season followed by ST4. A higher molecular weight PAH benzo(b)fluoranthene and benzo(k)fluoranthene had highest concentration at ST2 and this could be responsible for the higher value at this location in rainy season. ST1 recorded lowest concentration of PAHs in both dry and rainy season. This finding is similar to the work done by Bayowa and Agbozu at same location on sediment samples. It corroborates their reports that the characteristics of the different locations determine the type and quantity of PAHs found there; irrespective of the season (Bayowa \& Agbozu, 2016). In addition, previous work done by Inengite $e t a l$. on sediment samples of Kolo Creek in Niger Delta area reveals a similar trend in which the station with the highest value in dry season was the same with the highest in the rainy season and the one with the lowest in dry season was also lowest in rainy season (Inengite et al., 2010). These findings however vary from the work done by Koukau et al., at Grand-Lahou lagoon in Cote-d'-voire (Kouakou et al., 2015). In their study, lower concentrations were detected in dry season than rainy season. They also agreed that in addition to the seasons, the characteristics of the different locations were responsible for the concentration detected (Kouakou et al., 2015).

\section{PAH Variations base on Characteristics of the different Locations}

Ekpan ST1 is along a busy expressway and the sampling point was under the bridge. This location is peculiar because of the busy highway that could generate PAHs from vehicular emissions that are of pyrolytic source. One major characteristics of this location is that there are not much human population here. The river could be a drain receiving waste water from neighbouring residential areas and industries. PAHs at this location were below detection limit in rainy season. Apart from benzo(a)pyrene and benzo(g,h,i)perylene (which are higher ringed PAH), most of the PAHs here were either detected in low quantity or below detection limit in dry season. The characteristics of this location and the sample source (soil) are believed to have determined the type of PAHs and concentration detected. In the work done by Bayowa and Agbozu on sediments, fewer ringed PAHs were detected here in the dry season but mostly below detection limit in rainy season while higher ringed PAHs were below detection limit in dry season and rainy season (Bayowa \& Agbozu, 2016). This could help explain that, when compared to sediment, soil is not a sufficient sink for determining PAHs levels in the environment.

The second sampling point Ogunu ST2 is a local community that has been upgraded by virtue of the presence of oil multinational companies in the area. The people in this community are majorly petty traders, farmers, fishermen or just idle. The sampling point is close to a river also suspected to be an avenue for illegal petroleum product marketing activities. There is also a local public toilet and a refuse dump around it. Apart from benzo(a)anthracene which was not detectable at this location in both rainy and dry season, all the other PAHs analysed in this study were found at this location. This is similar to the work done by Bayowa and Agbozu on sediments at same location around the same period. In their study, all the PAHs analysed were detected in the samples (Bayowa \& Agbozu, 2016). The activities at this location are believed to be responsible for the various PAHs detected there.

At Ugboroke ST3, this location is characterised by the presence of many local inhabitants. It has swampy forest with timber trees, palm trees and fruit trees. Activities around this location are bush burning, home cooking and residential burning of garbage. Higher ringed PAHs of the four to six rings constitute the major PAHs found at this location (although three ringed anthracene and phenantherene were also detected) and they were majorly in the dry 
season. Bayowa and Agbozu in their analysis of sediments, found all the PAHs they analysed in their study apart from four-ringed fluoranthene in both dry and rainy season (Bayowa \& Agbozu, 2016).

At Okotie sawmill ST4; there were quite a few industries around this location. The sampling point was close to a plank sawmill, and a houseboat and water vessel construction company. Other industrial activities around this location includes: a bottling company, an engineering firm and laboratory services. Apart from chrysene, all the PAHs analysed in this study were detected at this location. And they recorded high concentration in dry season and rainy season. Bayowa and Agbozu also detected all the PAHs they analysed in sediments at this location in both dry and rainy season (Bayowa \& Agbozu, 2016). Similarly, Ana et al. analysed surface waters and discovered that the highest amount of the various PAHs analysed were detected in the highly industrialised area (Ana et al., 2011).

The control point Agbarho ST5, is a town outside Warri (study location). The site is characterised by an open abattoir and a meat market. As a result of which there are usually herds of cattle grazing by the riverside. PAH with highest concentration in the soil sample at this location was benzo(g,h,i)perylene $\mathrm{B}(\mathrm{ghi}) \mathrm{P}$. Though it was detected in both rainy and dry season, the larger mean concentration of 0.5195 $\mathrm{mg} / \mathrm{kg}$ was detected in the dry season. Studies have revealed that microbial activities in certain environment could lead to increase production of PAH such as B(ghi)P (Obayori and Salaam, 2010). Therefore, the high concentration of BghiP here could be attributed to the microbial production of the PAH due to microbial activities in the abattoir area. This is similar to the study done by Inengite et al. on PAHs sources in Kolo Creek soil in Niger Delta area of Nigeria where it was found that concentration of BghiP was high near an abattoir (Inengite et al., 2010).

Lastly, according to source prediction analysis based on PAH diagnostic ratio done by Agbozu et al. on soil samples from the study location and control during similar periods, it was found that in the dry season, PAH source within Warri could be of petroleum origin, petroleum sources and petroleum combustion or of mixed sources and combustion origin (such as grass wood and coal combustion) while at the control point it is of petroleum combustion or petroleum origin (Agbozu et al., 2017). In the rainy season, PAHs in soil samples were predicted to be of petroleum origin, mixed sources and combustion origin within Warri and at the control point to be of petroleum origin and petroleum sources (Agbozu et al., 2017).

\section{CONCLUSION}

From the results of this study, the following conclusions were made:

- The total quantity of PAHs detected in the dry season are higher than those of the rainy season in marshy soil samples collected in Warri city in this study period

- Rainy season samples were majorly below detection limit

- $\quad$ Five-ringed benzo(a)pyrene had highest value for individual PAHs at a given point of $1.069 \mathrm{mg} / \mathrm{kg}$ and it was detected in dry season ST4 sample

- At the Control station, highest PAHs concentration was in dry season

- Locations with higher PAHs in dry season were also high in rainy season, And locations with low PAHs in dry season were also low in rainy season

- Characteristics of the different locations and the sample source are responsible for the type and quantity of PAHs detected at any season (dry or rainy)

- In dry season, PAHs in the study area-Warri are suggested to have come from more of anthropogenic pyrogenic activities than petrogenic sources.

\section{Funding Acknowledgement}

The authors acknowledge the financial support of $\mathrm{Mr}$ Olusegun Ayodeji Bayowa in funding this project.

\section{Competing Interests}

The authors declare that they have no competing interest.

\section{Authors' Contributions}

The article is a fraction of Adejoke Victoria Bayowa's M.Sc. Thesis at University of South Africa with Dr I.E. Agbozu as the supervisor. The article is therefore a product of joint effort with Mrs Bayowa generating the data from her research work and Dr Agbozu providing technical guidance.

\section{Acknowledgements}

Dr I.E. Agbozu for supervision and useful advice; Mr Oghama Osayomwanbor for technical support; Thermosteel Nigeria Limited for ensuring accuracy of results

\section{References}

1. Agbozu IE, Bayowa AV, Oghama OE. 2017. Source Prediction of Polycyclic Aromatic Hydrocarbons in Marshy Soils and Sediments in Warri City, Southern Nigeria. Chem. Sci. Rev. Lett. 6(21), 252-268 Article CSO 72048022.

2. Ana GREE, Sridhar MKC, Emerole GO. 2011. Contamination of Surface waters by Polycyclic Aromatic Hydrocarbons in two Nigerian Coastal Communities. Journal of Environmental Health Research, 11(2): 77-85. 
3. Bayowa AV, Agbozu IE. 2016. Seasonal variation of PAHs in marshy sediments from Warri City, Nigeria. Int. J. Biol. Chem. Sci. 10(5): 2379-2391, ISSN 1997-342X (Online).

4. Botkin B, Keller E. 2005. Environmental Science-Earth as a Living Planet ( $5^{\text {th }}$ edition). Wiley: U.S.A.

5. Delgado T. 2000. The occurrence and regulation of Polycyclic Aromatic Hydrocarbons (PAHs) in groundwater and soil. Smart News, 2(5): 1-31.

6. Egborge ABM, Olomukoro JO. 2004. Hydrobiological studies on Warri River Nigeria Part II. African Journal Online, 12(1): 9-23. http://dx.doi.org/10.4314/tfb.v12i1.20872

7. Ekonomiuk A, Malawska M, Wilkomirski B. 2006. Mires and peat Polycyclic Aromatic Hydrocarbons (PAHs) in peat cores from Southern Poland: Distribution in stratigraphic profiles as an indicator of PAH sources. International Mire Conservation Group and International Peat Society. 5(1) ISSN: 1819-754X http://www.mires-and-peat.net/.

8. Environmental Forensics-Contaminant Specific Guide (EFCS) 2010. Environmental Forensics Case Studies for the non-technical person: About Coal Tar and Polycyclic Aromatic Hydrocarbons (PAHs), Morrison R, Murphy B (ed).

Pg. 222

http://www.truthaboutcoaltar.com/aboutcoaltar.html.

Academy Press: USA

9. European Food Safety Authority (EFSA) 2008. Scientific Opinion of the Panel on Contaminants in the Food Chain on a request from the European Commission on Polycyclic Aromatic Hydrocarbons (PAHs) in Food. The EFSA Journal, 724 :

$1-114$.

http://www.efsa.europa.eu/efsajournal/doc/724.pdf.

10. Inengite AK, Oforka NC, Osuji LC. 2010. Evaluation of Polycyclic Aromatic Hydrocarbons (PAHs) in sediment of Kolo Creek in the Niger Delta. International Journal of
Applied Environmental Sciences, 5(1):127-143. ISSN: $0923-$ 6077

11. Karlsson K, Viklander M. 2008. Polycyclic aromatic hydrocarbons (PAH) in water and sediment from gully pots Water, Air and Soil Pollution, 188(1): 271-282. DOI: 10.1007/s11270-007-9543-5

12. Kouakou R, Kouassi AM, Kwa-Koffi EK, Gnonsoro UP, Trokourey A. 2015. Distribution of Polycyclic Aromatic Hydrocarbons (PAHs) in a tropical coastal lagoon (GrandLahou lagoon, Côte d'Ivoire). Int. J. Biol. Chem. Sci., 9(2): 1120-1129. DOI : http://dx.doi.org/10.4314/ijbcs.v9i2.47

13. Neff JM, Stout AS, Gunstert DG. 2005. Ecological risk assessment of Polycyclic Aromatic Hydrocarbons (PAHs) in sediments: identifying sources and ecological hazard. Integrated Environmental Assessment and Management, vol. 1(1): 22-23. SETAC

14. Obayori SO, Salam LB. 2010. Degradation of Polycyclic Aromatic Hydrocarbons (PAHs): role of plasmids Scientific Research and Essays Academic Journals, 5(25): 4093-4106. ISSN: 1992-2248.

15. Padmini A, Patri M, Phanithi PB. 2009. Polycyclic Aromatic Hydrocarbons (PAHs) in Air and their neurotoxic potency in association with oxidative stress: a brief perspective. Annals of Neurosciences, 16(1)

DOI: 10.5214/ans.0972.7531.2009.160109

16. Teaf CM. 2008. Polycyclic Aromatic Hydrocarbons (PAHs) in urban soil: a Florida risk assessment perspective. International Journal of Soil, Sediment and Water, 1(2). ISSN: http://scholarworks.umass.edu/intIjssw/vol1/iss2/2

17. World Health Organisation WHO 2003. Guidelines for drinking water quality-Polynuclear Aromatic Hydrocarbons (PAHs) in drinking water: Health criteria and other supporting information. World Health Organisation, Geneva, 2(2):

WHO/SDE/WSH/03.04/59

\section{FIGURES AND TABLE}

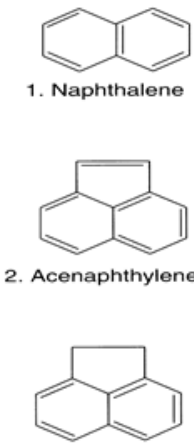

3. Acenaphthene

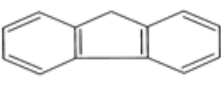

4. Fluorene

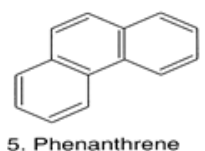

5. Phenanthrene

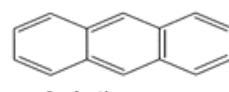

6. Anthracene
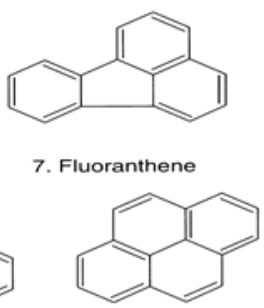

8. Pyrene

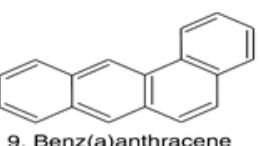

9. Benz(a)anthracene

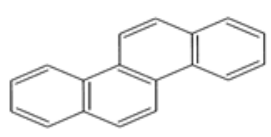

10. Chrysene
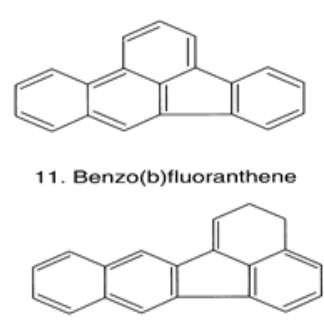

12. Benzo(k)fluoranthene
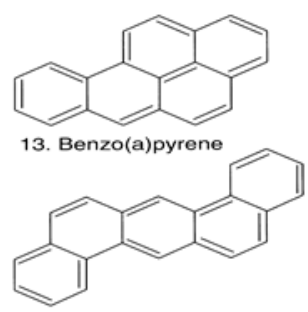

14. Dibenz(a,h)anthracene

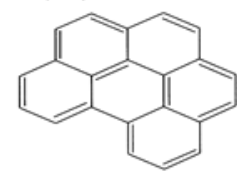

15. Benzo(ghi)perylene

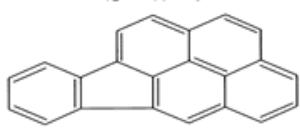

16. Indenol (1,2,3-cd)pyrene

Figure 1: The structure of the 16 PAHs that are termed as priority pollutants by the World Health Organisation 


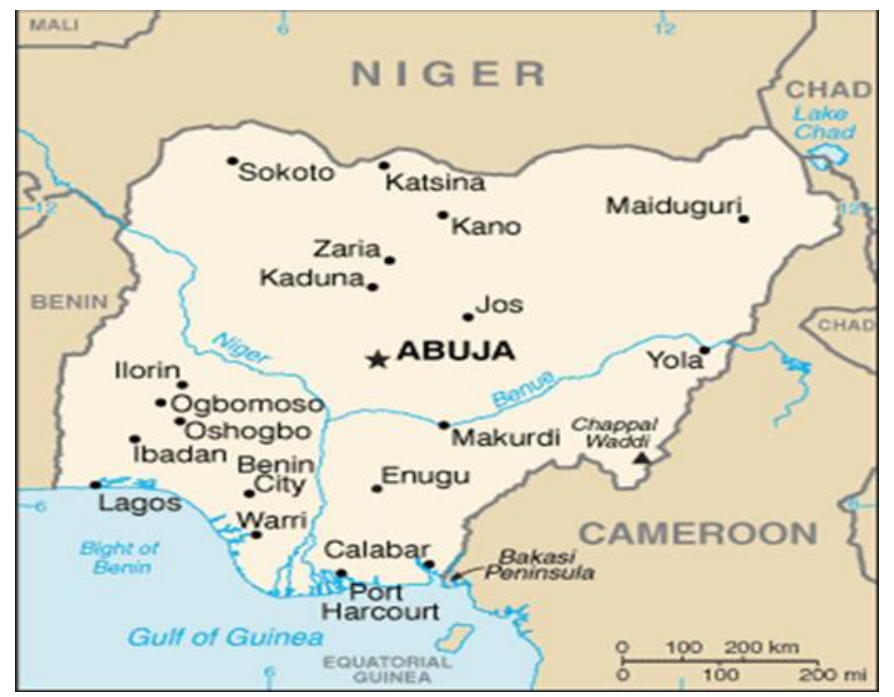

Figure 2: Map of Nigeria, showing Warri in lower Niger Delta region

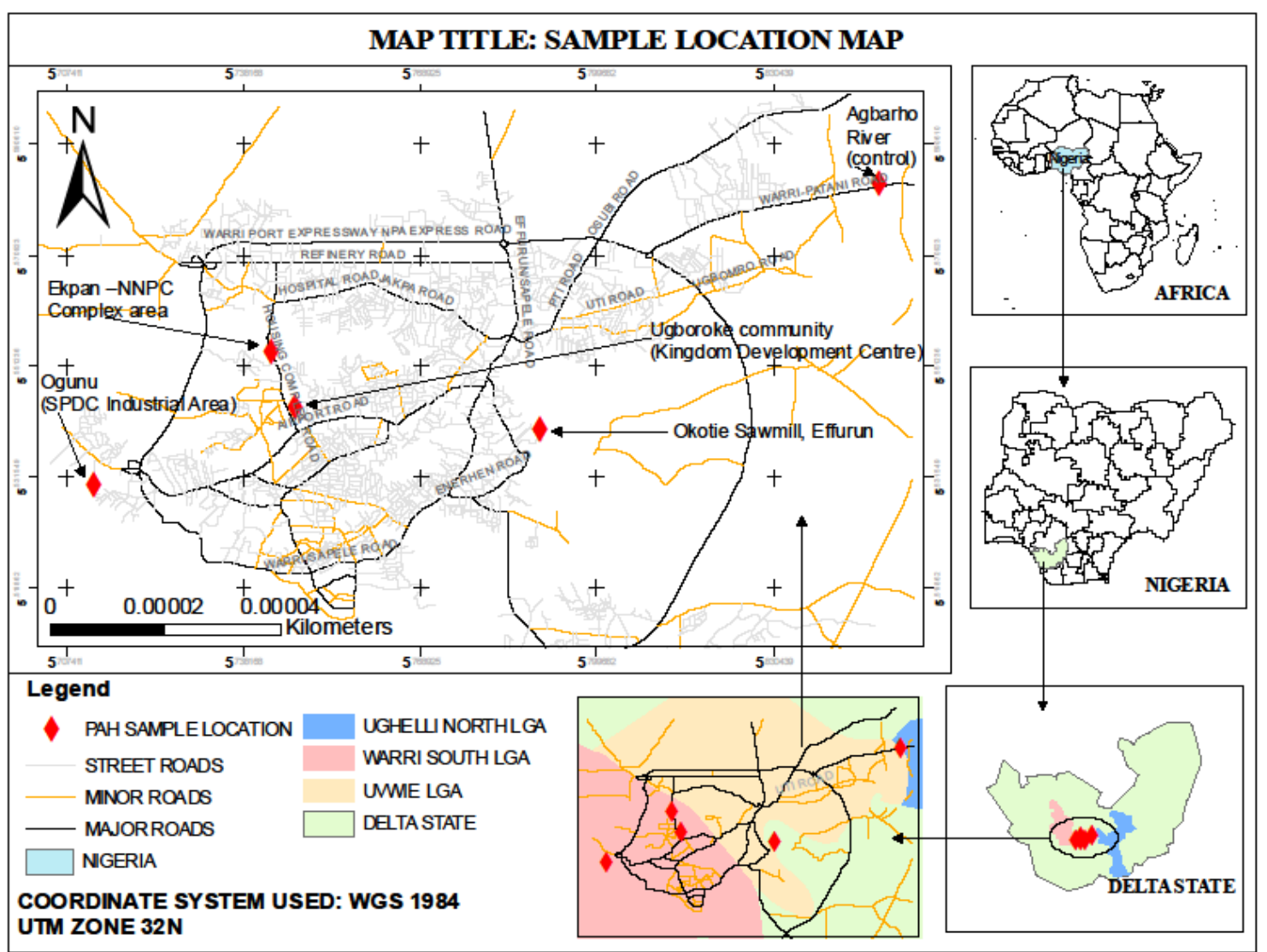

Figure 3: Sample location Map 


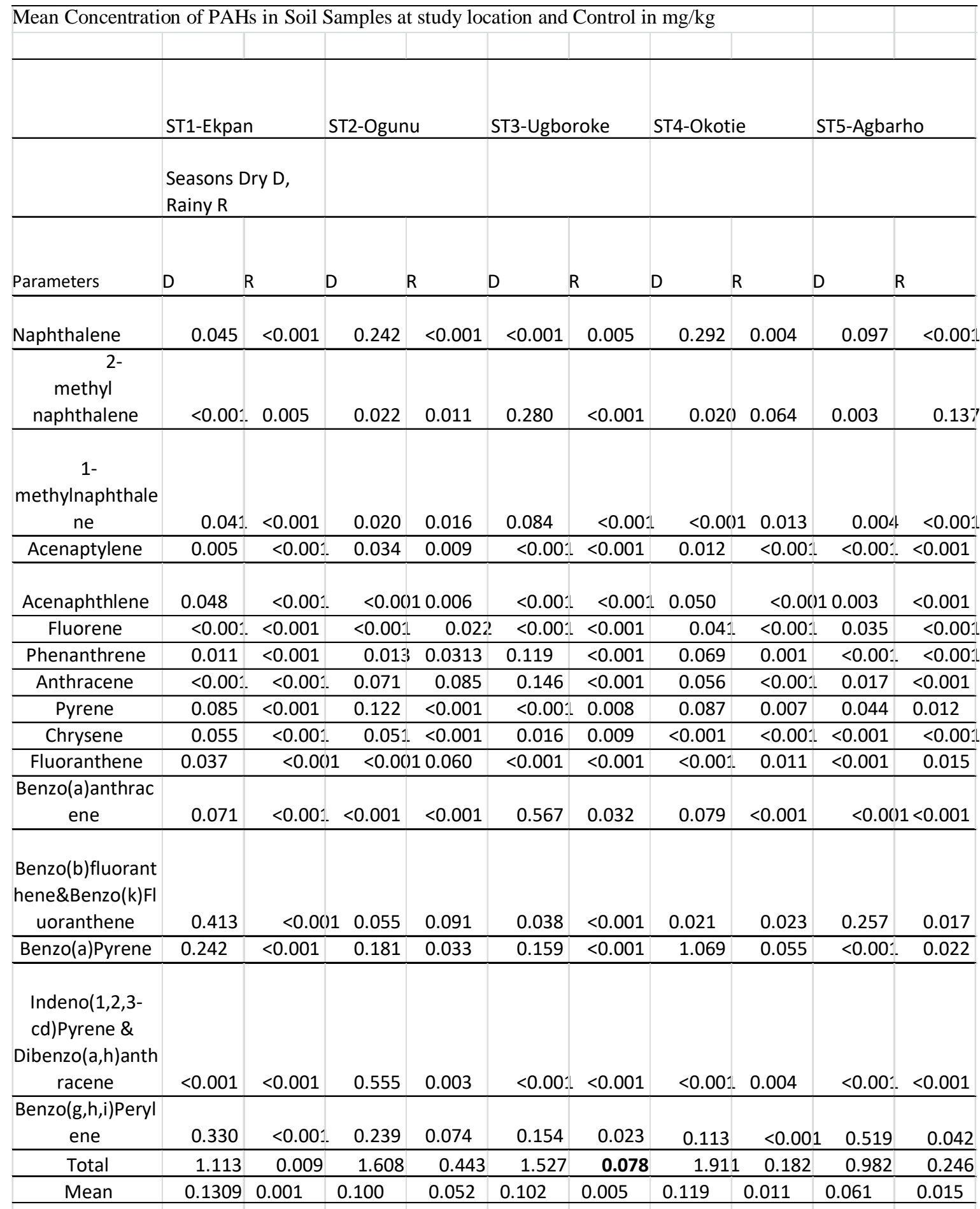

